\title{
Age Determination, Age Distribution and Sex Ratio in Mole Population
}

\author{
Oluwadare FUNMILAYO ${ }^{1}$
}

\begin{abstract}
Funmilayo O., 1976: Age determination, age distribution and sex ratio in mole populations. Acta theriol., 21, 14: 207-215 [With 1 Table \& 3 Figs.].

The age distribution of four mole (Talpa europaea Lin nae us, 1758) populations was determined by taking four direct measurements on the inner cusps, above the gum line, of the second upper molar teeth At the end of the single annual breeding period, usually August, after babies were weaned, a mole population contained five age groups namely juveniles (approximately 4 months old) and adults in the approximate age categories in months: $16,28,40,52$. Only a small proportion of moles $(6.6 \%)$ survived longer than 36 months. There was a preponderance of juveniles in all populations examined. The age distribution obtained by tooth measurements compared very favourably with that obtained by theoretical calculations. The age distribution of mole populations is affected by dispersal, previous trapping and drastic changes in weather and soil conditions which cause the death of moles. There were no sexual differences in the age distribution in the populations studied. The weight of the skull is not a reliable index of the age of moles in either sex but males have, on average, significantly heavier skulls than females.

[Dept. Agric. Zool., School Agric., Univ. Edinburgh, Edinburgh EH9 3JG, Scotland]
\end{abstract}

\section{INTRODUCTION}

Adult and juvenile moles can easily be distinguishesd in June when juveniles are distinctly lighter and slimmer than adults. From July onwards to about December juveniles are as heavy as adults and separation can be made only on the basis of internal sexual morphological differences. From about December moles can be separated into age categories only on the basis of tooth length or tooth wear. Tooth length is a particularly suitable criterion for aging moles for two reasons: (a) Moles have a single short annual reproductive period ( $\mathrm{G}$ o d f r e y \& Crowcroft, 1960) so that distinct age groups are formed within a population. (b) The roots of the teeth are closed in moles which precludes the replacement of worn parts by continuous growth so that tooth. wear is reliably uniform among moles in a population.

1 Present address: Dept. Agric. Biol., Univ. Ibadan, Ibadan, Nigeria. 
Larkin (1948) used the two highest inner cusps of a second upper molar tooth to determine age in moles. He drew the profile of each tooth with a camera lucida and measured the wear in relation to that of a tooth with little or no wear. He did not measure the length of the tooth. Age determination in moles by tooth wear has also been carried out by Stein (1950), Deparma (1954) Godfrey \& Crow croft (1960) and $\mathrm{Skocz}$ en (1966). Previous results have indicated variations in the age distribution in different populations which, according to $\mathrm{Lark}$ in (1948) and S k o c z en (1966), are related to the previous history of the populations. The maximum life span of the mole has not been conclusively determined. L a r kin (1948) and Stein (1950) gave the maximum life span to be three years but D e parma (1954) and Skoc z e ń (1966) found four year old moles. According to D e p a r m a (1954) and Godfrey \& Crow croft (1960) a mole cannot live longer than five years because of severe tooth wear.

All previous workers evaluated age composition in mole populations by comparing the degree of tooth wear and without making direct measurements of individual tooth length. Degree of tooth wear is a subjective method susceptible to errors of personal judgement. Direct measurement of tooth length was therefore tested as a possible improvement over previous methods because it has the advantage of the absence of subjectivity in the estimates which gives it statistical advantage over comparative methods. An attempt was also made to use the weight of the skull for age determination.

\section{MATERIALS AND METHODS}

Moles were killed with "Duffous « traps in four grassland pastures in Boghall farm, South-east Scotland. There was no record of previous trapping in Boghall glen and Fulford field. The other two sites, Leip field and Bilston field were trapped free of moles in 1967/68 winter but were reinfested again in autumn 1968 . Fulford and Leip were two adjacent fields separated by a small stream which freezes in winter and dries up in summer and therefore did not prevent the movement of moles between the two fields.

All moles in Boghall were trapped between March and August 1968 and all those in Fulford, Leip and Bilston fields in January 1970.

The skull of each mole was thoroughly cleaned and dried to constant weight in an oven. Ten left second upper molar teeth, from two juveniles and eight adults, were first examined in the Boghall glen collections to determine the pattern of tooth wear. Each cleaned tooth was mounted in "Plasticine" on a slide so that all its inner cusps were visible. Drawings of wear surfaces were made. Comparison of adult and juvenile teeth indicated four wear surfaces on each tooth, the three inner cusps and the central ridge between them. The length of each tooth (height above gum line) was measured in relation to the three inner cusps (Fig. 1) using a micrometer eye-piece. The mean of four measurements taken on each tooth was calculated. Both right and left teeth were measured from Leip, Fulford and Bilston 
field moles and the average of the measurements for both teeth was used. Each scale division of the eye-piece micrometer represented $0.86 \mathrm{~mm}$, calibrated by using an objective graticule with 100 divisions each equal to $0.01 \mathrm{~mm}$.

The natural variation in tooth length in juveniles was determined first. Their mean tooth length varied between 2.07 to $2.32 \mathrm{~mm}$ for juveniles obtained from Boghall glen which gave a natural variation in tooth length of $0.26 \mathrm{~mm}$ within this age group. $0.26 \mathrm{~mm}$ was therefore chosen as a reliable class interval which was used to draw the histogram of tooth length on which age distribution was based. The sex ratio in each age group was determined to detect any sexual bias in age distribution.

\section{RESULTS}

\subsection{Pattern of Tooth Wear}

Fig. 1 shows the left upper second molar tooth of a juvenile mole. The letters $a, b, c$, and $d$ represent the four measurements taken on each tooth. The inner cusps of the left second upper molar teeth of moles aged

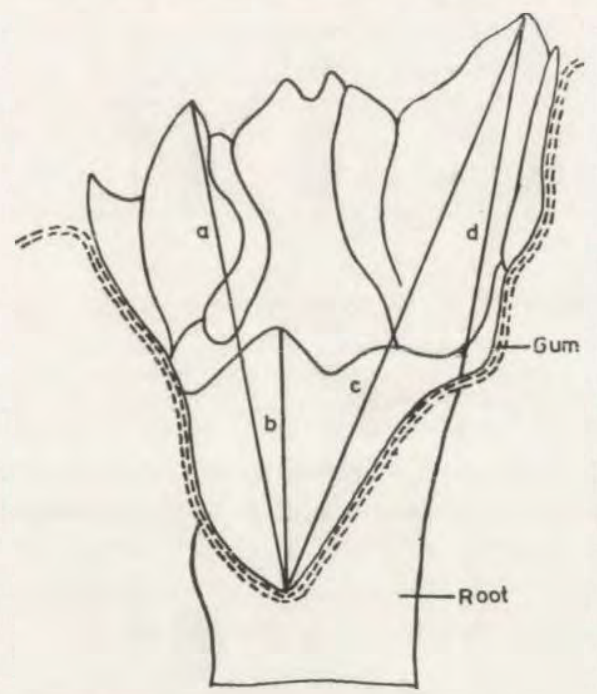

Fig. 1. The inner cusps of the left second upper molar tooth of a juvenile mole. $a, b, c, d$ were measured.

approximately between 4 months (juvenile) to 52 months are shown in Fig. 2. The shaded areas represent wear surfaces. The cusps are robust and pointed in juveniles but thin and blunted in older moles. The space between the cusp is raised into a ridge in juveniles but in adults the ridge is replaced by a furrow which widens and deepens as the age of the mole increases. The extent of the furrow is indicated by broken lines in Fig. 2. The cusps and the central ridge disappear almost completely in moles aged 45 months and above. The rate of wear of a particular cusp 
varies in different teeth indicating that a clear segregation into age groups could not be obtained by measuring a single cusp. The mean tooth length was similar in left and right second upper molar teeth which showed that the overall wear was reasonably uniform in similar teeth on either side of the jaws and that measurement of a tooth of one side was enough to give a reliable age determination.

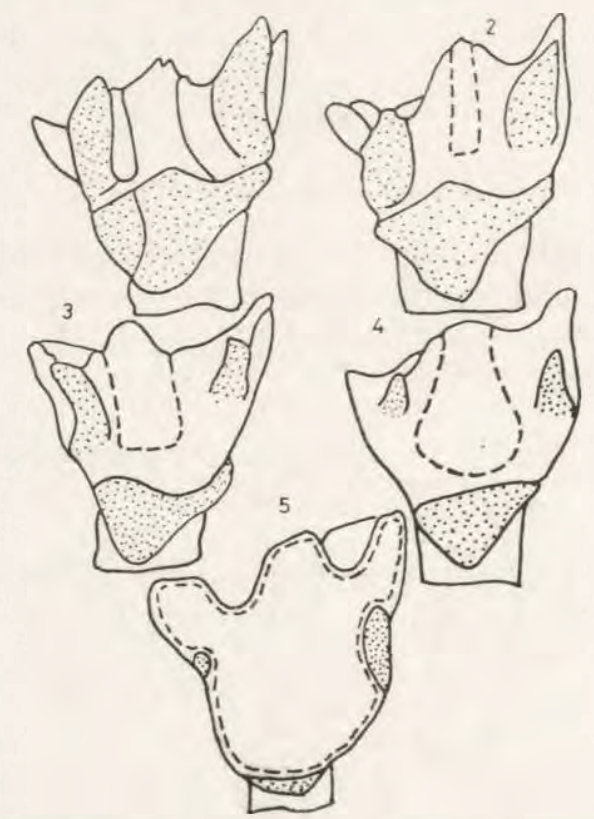

Fig. 2. Inner cusps of the left second upper molar showing the extent of tooth wear in different age groups $1-4$ month old; $2-16$ months old; $3-28$ months old; $4-40$ months old; $5-52$ months old.

\subsection{Population Age Distribution}

The percentage number of moles in each age group in Boghall glen and in Leip, Fulford and Bilston fields are presented in Fig. 3. The single annual reproductive period in the present study area occurs in March to June. Majority of females are pregnant in April, babies are born early in May and weaned early in June. A mole population in April (as in Boghall glen), just before babies are born, will contain only adults in the approximate age categories in months: $12,24,36,48$ and possibly 60. Since babies are born early in May, the population in August of the same year will contain juveniles (approximately 4 months cld) and, adults in the approximate age categories in months: 16, 28, 40 and possibly 52. In January the following year this population (as in Leip, Fulford and Bilston fields) will contain juveniles, which are by now 
sub-adults ( 9 months old) and, adults in approximate age groups in months: $21,33,45$ and possibly 57 .

$\mathrm{B}$ og h a 11 glen: The population ( $\mathrm{N}=135)$ consisted of $35.6 \%$ juveniles and $64.4 \%$ adults in the age groups in months: $16(31.9 \%), 28(25.2 \%)$, $40(6.7 \%)$ and $52(0.7 \%)$. The relatively low proportion of juveniles was due to trapping during the breeding period. Some females killed in March to June did not contribute to the annual reproduction, and some babies undoubtedly died from lack of parental care after their parents were killed. The proportion of 28 months old moles in the population was low. This may be due to the very dry weather in 1968 between midMay to Mid-June and late July to early August, during which periods some moles were picked up on the soil surface. The heavily worn teeth

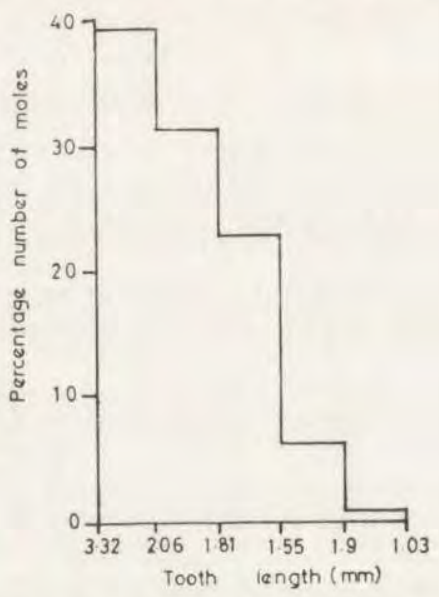

Fig. 3. Tooth lenght and age distribution of moles $(\mathrm{N}=181)$ captured in Boghall farm.

$2.32-2.06 \mathrm{~mm}$ tooth length $=4$ months old; $2.06-1.81 \mathrm{~mm}$ tooth length $=16$ months old; $1.81-1.55 \mathrm{~mm}$ tooth length $=28$ months old; $1.55-1.29 \mathrm{~mm}$ tooth length $=40$ months old; $1.29-1.03 \mathrm{~mm}$ tooth length $=52$ months old.

(Fig. 2) of the only mole aged 52 months indicated that it could not survive for a much longer period.

L e i p field: The population $(\mathrm{N}=12)$ consisted of three age categories in months; $9(66.7 \%), 21(25.0 \%)$, and $33(8.3 \%)$. This was a recolonized area which might account for the high proportion of juveniles/subadults.

F u lf ord field: The population $(\mathrm{N}=21)$ consisted of four age groups in months; $9(38.1 \%), 21(42.9 \%), 33(9.5 \%)$ and $45(9.5 \%)$. The low proportion of 9 months old moles was due to the movement of this age group into the less densely populated Leip field.

A more balanced age distribution ( $48.5 \% 9$ months old, $36.4 \% 21$ months old, $9.1 \% 33$ months old and $6.1 \% 45$ months old) was obtained when 
moles from Leip and Fulford fields were considered as a single population. The two moles aged 45 months had heavily worn teeth, suggesting low survival potential.

Bilst o n field: The population $(\mathrm{N}=13)$ consisted of $53.8 \% 9$ months old, $15.4 \% 21$ months old and $30.8 \% 33$ months old. The low proportion of 21 month old moles was probably due to the drought in the summer of 1968 as explained for Boghall glen. The absence 45 months old moles was probably due to the trapping-out of this field in $1967 / 68$ winter. This age group was absent from Leip field which was similarly trapped-out at the same period.

A 11 sites: Moles captured in the four fields were considered as if they were all captured during the same period, say August 1969, to obtain a single age distribution for all populations $(\mathrm{N}=181)$. The age distribution (Fig. 3) in all mole populations considered together, in August 1969, was $71(39.2 \%)$ juveniles, $57(31.4 \%) 16$ months old, $41(22.7 \%) 28$ months

Table 1

Sex ratio in different age groups in mole populations.

\begin{tabular}{|c|c|c|c|c|}
\hline Age group & $\begin{array}{l}\text { No. in } \\
\text { Male }\end{array}$ & $\begin{array}{l}\text { age group } \\
\text { Female }\end{array}$ & $\begin{array}{l}\text { Ratio of male to female } \\
\text { in age group }\end{array}$ & $\begin{array}{l}\chi^{2} \text { of } \\
\text { ratio }\end{array}$ \\
\hline 4 months & 39 & 32 & $1: 0.82$ & 0.69 \\
\hline 16 months & 29 & 28 & $1: 0.97$ & 0.02 \\
\hline 28 months & 21 & 20 & $1: 0.95$ & 0.02 \\
\hline 40 months & 7 & 4 & $1: 0.57$ & 0.82 \\
\hline 52 months & 1 & 0 & $1: 0$ & - \\
\hline $4-52$ months & 97 & 84 & $1: 0.87$ & 0.94 \\
\hline
\end{tabular}

Sex ratio is not significantly different from a $1: 1$ ratio in any age group. $\chi^{2}$ at $P_{0.05}=3.84$

old, $11(6.1 \%) 40$ months old, and one $(0.6 \%) 52$ months old. Juveniles formed the largest proportion of all populations and the proportion of moles in an age category decreases as the age increases.

\subsection{Sexual Differences in Age Distribution}

The age distribution in male and female moles is shown in Table 1. The results revealed no major sexual differences $(P<0.05)$ in age distribution, the two sexes occurring in approximately equal proportions in each age group and in the whole populations. The sexual composition of each age group and the overall sex ratio have not been influenced by trapping bias since all moles in each site were trapped.

\subsection{Weight of Skull as Index of Age}

Skull weight was related to sex and is significantly higher in males than in females. The mean $( \pm \mathrm{S}$. E.) weight of skull was $0.6 \pm 0.01 \mathrm{~g}$. in 
males and $0.5 \pm 0.01 \mathrm{~g}$. in females giving a mean ( \pm S. E.) difference of $0.1 \pm 0.01 \mathrm{~g}$. ( $t$ value of difference $=10.0$ and $t$ at $P_{0.01}=2.70$ ). A clear segregation into age groups was not obtained when the weight of skull was plotted into histograms first, for all moles, and then separately, for each sex, which shows that skull weight is not related to age in moles of either sex.

\section{DISCUSSION}

Distinct age groups are formed in a mole population and there is a natural variation in tooth length within an age group. It was assumed that this natural variation in tooth length is the same in each age group in a population. Moles in a population feed on the same kind of food and provided the texture of the surface soil is uniform the teeth will wear at approximately the same rate in all moles. The natural variation in tooth length will therefore remain reasonably constant throughout the life span of each age group. The reliability of the results of age determination from tooth length will therefore depend on the correct determination of the natural variation in tooth length within an age group. This variation is best determined, in June to August, from a large number of juveniles, which is the only age group that could be identified morphologically. Variations in soil texture and hardness of teeth in individual moles in a population will cause the teeth in individual moles to wear at different rates and will therefore decrease the accuracy of the results. This tendency has been noted by Larkin (1948) and Godfrey (in Godfrey \& Crow croft, 1960). However, all moles in the present study were collected in grassland pasture with similar soil texture (loam to sandy-loam) and no evidences suggesting differential tooth wear were obtained. The clear segregation into age groups in the different populations is a good indication of the fact that tooth wear and the natural variation in tooth length in each age group was, for practical purposes, reasonably uniform.

Many factors affect the age composition of a mole population (L a r k in, 1948; Skoczeń, 1966). Trapping in the breeding season, as was done in Boghall glen, and movement into less densely populated areas, as noted in Fulford field, reduced the proportion of juveniles in a population. On the other hand, the populations of recolonized areas, as in Leip and Bilston fields have a high proportion of juveniles. It was noted that adverse weather conditions also affect population age structure. A very dry summer and an unusually cold autumn could cause the death of moles mainly juveniles looking for new homes, by exposure to predators (S o u ther n, 1954; S k o c z en, 1962) or by causing starvation in moles which are unable to dig into the soil to obtain food. 
The accuracy of the present results can be checked against a theoretical calculation similar to that used by Godfrey \& Crow croft (1960). The calculation is based on the fact that the sex ratio in moles is $1: 1$ and a female produces a single litter of four babies in a year (A d a m s, 1903; Evans, 1907; Larkin, 1948). Therefore, starting with 1 male and 1 female juvenile moles, an undisturbed population in which each mole lived for 48 months will, at the end of the fourth breeding season, contain 162 moles. The population age composition will be $108(66.7 \%)$ juveniles, $36(22.2 \%) 12$ months old, $12\left(7.4^{\%} \%\right) 24$ months old, $4(2.5 \%)$ 36 months old and $2(1.2 \%) 48$ months old. The above theoretical age structure will not be obtained in a field population because of mortality and dispersal factors. However, subject to the various explanations aiready given, the age distribution in the present results compares favourably with the theoretical calculations which suggests that the method of age determination was reliable.

Acknowledgements: This work is part of a $\mathrm{Ph}$. D. thesis submitted to the University of Edinburgh. I am grateful to Dr. W. J. Guild who supervised the work. I also like to thank Dr. P. Osborne of the School of Agriculture, Edinburgh for providing the micrometer eye-piece and the objective graticule used in tooth measurements.

\section{REFERENCES}

1. A d a m s L. E., 1903: A contribution to our knowledge of the mole (Talpa europaea). Mem. Manchr. Lit. Phil. Soc. Old Series, 47: 1-39.

2. Deparma N. K., 1954: The method of age determination in moles. Bull. Soc. Nat. Moscou Biol., 59, 6: 11-25. [In Russian].

3. Evans W., 1907: The mammals of Edinburgh and Forth area. Supplementary Notes. Proc. Roy. Phys. Soc. Edinb., 16: 367-405.

4. Funmilayo O., 1970: Populations studies on the distribution om moles (Talpa europaea L.) relative to food supply and general habitat. Ph. D. thesis, University of Edinburgh: 1-254.

5. Godfrey G. \& Crowcroft P., 1960: The life of the mole. Museum Press: 1-152. London.

6. Larkin P., 1948: The ecology of mole ( $T$. europaea L.) populations. Unpublished D. Phil. thesis (Bodleian Library), Oxford: 1-134.

7. Skoczeń S., 1962: Age structure of the skull of mole, Talpa europaea Lin$\mathrm{n}$ a e us, 1758 from the food of buzzard (Buteo buteo L.). Acta theriol., 6: 1-9.

8. Skoczeń S., 1966: Age determination, age structure and sex ratio in the mole (Talpa europaea L.). Acta theriol., 11: 523-536.

9. Southern, H. N., 1954: Tawny owls and their prey. Ibis, 96: $384-410$.

Accepted, November 28, 1975. 
Oluwadare FUNMILAYO

OZNACZANIE WIEKU, STRUKTURA WIEKOWA I STOSUNEK PECI W POPULACJACH KRETA

\section{Streszczenie}

Określono wiek czterech populacji kreta Talpa europaea Linnae us, 1758 biorąc za pođstawę cztery pomiary wewnętrznych guzków $M^{2}$ (Ryc. 1). Przy końcu każdego okresu rozrodu, zwykle w sierpniu kiedy to młode osobniki są odchowane, populacja kreta składa się z pięciu grup wiekowych: młodych w wieku około 4 miesięcy i dorosłych w wieku: 16, 28, 40 i 52 miesięcy (Ryc. 2). Tylko znikoma część populacji $(6,6 \%)$ kreta żyje dłużej niż 36 miesięcy a we wszystkich populacjach udział młodych zaznacza się wyraźnie. Struktura wiekowa, określana na podstawie pomiarów starcia zębów wykazują dużą zgodność z rozkładem teoretycznym klas wieku (Ryc. 3). Struktura ta ulega zachwianiu pod wplywem migracji i śmiertelności zwierząt. Nie stwierdzono zróżnicowania w stosunku płci w poszczególnych grupach wiekowych (Tabela 1). Ciężar czaszki nie jest wiarygodnym wskaźnikiem wieku u kretów, i to zarówno u samic jak i u samców, choć u tych ostatnich czaszka jest zawsze cięższa niż u samic. 